\title{
THE ENTITY STRUCTURE OF THE CROSS-BORDER TOURISM PRODUCT
}

\author{
ANNA GARDZIŃSKA, ${ }^{1}$ BEATA MEYER, ${ }^{2}$ AGNIESZKA SAWIŃSKA ${ }^{3}$
}

Szczecin University, POLAND

${ }^{1}$ e-mail: anna.gardzinska@wzieu.pl

2 e-mail: beata.meyer@wzieu.pl

3 e-mail: agnieszka.sawinska@wzieu.pl

KEYWORDS | cross-border tourism product, entities creating a cross border tourism product, West Pomeranian Province and Mecklenburg-Vorpommern

ABSTRACT

A cross-border tourism product constitutes a compilation of tourism potential elements of a cross-border region which satisfy various tourist needs. Functioning of a cross-border tourism product is determined by many diverse factors such as, e.g. natural and anthropogenic values, transport accessibility, a type and quality of tourism and paratouristic infrastructure or a quality of the natural environment. Many entities on both sides of the border are involved in the process of creating a common product, including regional and local tourism organizations, local authorities and other entities interested in the development of tourism. Regions that can develop a common tourism product are the West Pomeranian Province and bordering to the west, the German Federal State of Mecklenburg-Vorpommern. In the process of creating a common product, a significant role is played by entities at a regional level. However, due to the dissimilarity of the Polish and German government systems, the extent of their involvement in the creation of a cross-border tourism product is different. The objective of the article is to indicate entities involved in the process of creating a cross-border tourism product and to describe their role on the example of the West Pomeranian Province and Mecklenburg-Vorpommern.

\section{Introduction}

The processes of internationalization in tourism definitely changes previous methods and forms of tourist service and the importance of the quality of tourism services increases. The models of recreation, customer market attitudes as well as expectations towards tourism products change. In the age of intensified competition, which is much visible also between tourism regions, an ability 
to develop tourism products appropriately becomes a key factor in terms of a long-term competitive strategy of a region.

Due to their geographical location, cross-border regions have to focus on creating common tourism products which use tourism potential of a cross-border region. Functioning of such tourism products brings financial benefits as well as enriches a tourism offer of regions where such a product exists. Many entities are involved in the creation of a cross-border tourism product, mainly regional and local tourism organizations, tourism enterprises, local authorities and other institutions interested in the development of tourism in a cross-border region. A condition necessary for a cross-border tourism product to be created and function is cooperation between particular entities at local, regional and macro-regional levels.

The objective of the article is to indicate entities involved in the process of creating a crossborder tourism product and to describe their role on the example of the West Pomeranian Province and Mecklenburg-Vorpommern.

\section{Cross-border tourism product and the process of its creation}

The term tourism product has been analysed in the secondary sources by many authors. It stems from the complexity and diversity of a tourism product as well as from a perspective on the issue. In scientific studies, there can be found definitions which emphasize a service nature of a tourism product and describe it as a set of goods and services which a tourist uses and consumes when travelling. ${ }^{1}$ The tourism product is also considered in terms of tourism values which are one of the main motives for travelling by tourists. When defined like that, the tourism product consists of two basic components: tourism goods and facilities as well as tourism services. Tourism goods and facilities include the so-called basic goods which are related to the term tourism values, and complementary goods and facilities - called tourism infrastructure. Tourism values constitute a dominant goal of travelling, whereas tourism infrastructure enables stay, journey and use of these values. ${ }^{2}$ The view on the tourism product may be expanded by psychological elements which enable taking account of benefits, pleasures and satisfaction which may result from its purchase. ${ }^{3}$

The tourism product may be also considered from a spatial perspective. According to E. Dziedzic, the tourism product of a region consists of material and non-material elements constituting the basis for an idea and expectations existing in the tourist mind related to a stay in a given place. ${ }^{4}$ J. Kaczmarek, A. Stasiak, B. Włodarczyk describe the tourism product of a region

1 J.Ch. Holloway, Ch. Robinson, Marketing for Tourism, PWE, Warsaw 1997, p. 114.

${ }^{2}$ S. Wodejko, Ekonomiczne zagadnienia turystyki, Wyższa Szkoła Handlu i Prawa w Warszawie, Warszawa 1998, pp. 24-28.

${ }^{3}$ V.T.C. Middleton, Marketing w turystyce, Polska Agencja Promocji Turystyki, Warszawa 1996, p. 87-88.

${ }^{4}$ E. Dziedzic, Obszar recepcji turystycznej jako przedmiot zarządzania strategicznego, „Monografie i Opracowania” nr 442, SGH, Warszawa 1998, p. 9. 
as "an internally complex set of elements distinguished due to their particular location in space characterized by tourism values." 5

One kind of the tourism product of a region is cross-border tourism product whose nature and concept have not been sufficiently elaborated in scientific studies and articles. Assuming that the cross-border tourism product is a category of a spatial product, thus the product offered by a specific region (in this case, a cross-border region) can by defined as a set of goods and separate services or packages of related, coherent and complementary services which main aim is to satisfy needs of tourists when both planning a trip, travelling and staying in the cross-border region. The cross-border tourism product should not be considered as an equivalent to the tourism product of countries bordering each other. The cross-border tourism product is developed on the basis of the tourism product (or particular elements creating it) of at least two regions existing on both sides of the border. A condition necessary for such a product to function on the market is a possibility of tourists crossing borders freely.

Main elements of the cross-border tourism product are tourism values, tourism infrastructure and tourism services provided in the cross-border region. Tourism values are those components of the cross-border tourism product which influence a selection, made by a potential tourist, of the cross-border region as a destination. Services enabling a tourist to stay outside their permanent place of living are elements which do not usually provide motives for travelling, however, their lack may prevent from using some, even attractive values. In addition, a low quality of an accommodation base or inconvenient transport connections may become a substantial obstacle to travelling itself. As part of tourism services, transport services are provided on the basis of transport infrastructure, what directly influences transport accessibility (external - enabling a tourist to move from a place of living to a place where a tourism product exists, and internal - enabling a tourist to move across a cross-border region) which, together with tourism infrastructure, plays a significant role in the functioning of the cross-border tourism product. Moreover, such a product can exist effectively on the market when it is recognizable and identifiable by tourists. Therefore, it is very important to include it in a common idea, concept and promotion which increase competitive advantage over other tourism products of a region.

As part of the cross-border tourism product, tourists can combine its elements individually through the purchase of partial services or specialized entities (e.g. travel agencies) can create tourism packages with a common programme, promotion and price.

Thus, the cross-border tourism product is a specific area product which is characterized by the following assumptions:

- it is created from a part of tourism potential of a cross-border region combined into one product with a common name, idea and promotion,

- management of this product is the task of tourism entities located on both sides of the border in a cross-border region,

5 J. Kaczmarek, A. Stasiak, B. Włodarczyk, Produkt turystyczny, pomyst, organizacja, zarzadzanie, Polskie Wydawnictwo Ekonomiczne, Warszawa 2005, p. 76. 
- this product is consumed by tourists of both adjacent countries as well as domestic and foreign tourists,

- the creation of the cross-border tourism product stimulates the development of services related to its consumption,

- the majority of funds allocated to the creation of such a product come from the EU aid programmes, however, ensuring constant effects of a product should be provided by entities creating it and local authorities.

The process of developing the cross-border tourism product is complex. The first stage of creating the cross-border tourism product is examining tourism potential of the cross-border region. In order to do that, tourism values (recreational, sightseeing and specialized) should be indentified and their role in terms of creating a common tourism product should be determined. The next stage is an analysis of the condition of infrastructure of an area where a tourism product exists (accommodation base, restaurant base, paratouristic infrastructure), as well as legal and technical determinants (important documents of a cross-border, domestic, regional, district and municipality nature) which are in correlation with activities connected with creating the tourism product. After examining tourism potential of a cross-border region, the tourism product to be launched on the market should be selected. The cross-border tourism product can be examined in terms of its type (a service, a facility, an event, an item, a festival, a trail) or a tourism function (e.g. the cross-border product of active, nature, sentimental, urban and cultural, rural tourism). When preparing the cross-border tourism product, it is also essential to indicate entities creating it and to specify their role in its functioning.

\section{Importance of entities in the process of creating the cross-border tourism product}

Taking account of its structure, creating the cross-border tourism product requires involvement of a wide range of public and private entities. A scope and number of involved entities as well as their role in servicing tourism movement depend on a structure and nature of a given product. Nevertheless, considering particular universal features describing a structure of the majority of regions of tourism products, including cross-border products, it is possible to specify the ones that play a key role in this process. These are tourism policy entities. From the perspective of entities developing tourism policy, there can be distinguished: tourism policy at an international level, tourism policy at a domestic level, tourism policy at regional and local levels. ${ }^{6}$

Tourism policy entities at an international level are mainly international tourism organizations, however, their influence on creating the tourism product of a cross-border region is insignificant. An international entity that takes part in creating a cross-border tourism product is a Euroregion. It is an association registered in accordance with law of a given country and, as part of which, common decision-making and executive bodies are formed. The main reasons for Euroregions to be founded are common or similar interests resulting from their proximity. These interests may be also connected with peripherality of location which can result in economic neglect. As M. Greta

\footnotetext{
${ }^{6}$ W. Kurek (ed.), Turystyka, Wydawnictwo Naukowe PWN, Warszawa 2007, p. 393.
} 
emphasizes, regardless of a scope and scale of activities, Euroregions are formed in order to jointly solve local problems of a cross-border nature such as, e.g. protecting and restoring the natural environment, responding to natural disasters, supporting economic growth, including building border infrastructure, supporting local movement and tourism, giving grounds for various human relations. ${ }^{7}$ There is no doubt that the fact that Euroregions exist is a significant incentive for many institutions and social groups to start cooperation with partners on the other side of the border. Thus, they play a significant role in the processes of integration.

At a national level, there are two fundamental types of bodies responsible for tourism policy, that is: National Tourism Administration (NTA) and National Tourism Organization (NTO). NTA is a government body in charge of formulating tourism policy as part of the economic strategy of a public administration, whereas NTO deals with extensive promotion of a national tourism product on the domestic and foreign markets. The participation of these two entities in creating a cross-border tourism product should be supportive. A relevant minister for tourism can create conditions for the development of the cross-border tourism product through supporting institutions or persons connected with it. While, the National Tourism Organization should promote crossborder tourism products and support activities connected with their development.

Entities at a regional level are of great importance in the process of creating the cross-border tourism product. They mainly include regional authorities and regional tourism organizations. Regional authorities cooperate with their counterparts existing on the other side of the border on the basis of agreements or declarations on mutual cooperation. The cooperation concerns many spheres of social and economic life, including tourism, and, as part of it, creating common tourism products. In this respect, regional authorities play a role of an entity supporting the creation of a common tourism product, mainly by preparing lands, premises and infrastructure for the development of a tourism product, cooperating with other entities when creating cross-border transport solutions which increase availability of the cross-border tourism product (e.g. a common tariff offer, the idea of "a common ticket").

Qualifications to hold the position of a coordinator in the process of creating the cross-border tourism product are showed by regional tourism organizations which can be the administrator of cooperation at a local level and, at the same time, synchronize the whole process of development and implementation of the cross-border tourism product. Their role focuses on combining elements of a cross-border tourism product located on both sides of the border as well as:

- exchanging information on a tourism offer of a region and tourism products locally available,

- searching for common tourism connections,

- finding how to combine a tourism offer,

- applying solutions in problematic areas,

- devising a concept of a cross-border tourism product,

- linking a cross-border tourism product with a common idea,

- promoting a cross-border tourism product under a common brand.

${ }^{7}$ M. Greta, Euroregiony a integracja europejska. Wnioski dla Polski, Wydawnictwo Uniwersytetu Lódzkiego, Łódź 2003, pp. 28-29. 
Local entities involved in the process of creating the cross-border tourism product are local authorities which build a partnership (the so-called twinning relationships) with units of local authorities (municipalities, districts, associations of cities/municipalities/districts) of an adjacent area. Partnership cooperation between local units is fundamental for cooperation between other units at a local level in creating the cross-border tourism product. At the same time, it is an essential form of cooperation taking account of the fact that when creating the cross-border tourism product, there are no criteria for product limitation (country or administrative borders). The cooperation of local authorities as part of partnership can concern:

- the exchange of experience and so-called best practice,

- joint infrastructure investments (including investments in particular elements of a cross-border tourism product),

- an increase of internal and external accessibility of a region,

- activities aimed at protection of the natural environment.

When partnerships of municipalities/cities notice common potential for creating the crossborder tourism product, they should draw up a common programme document concerning its creation and development. Such a document (a study, a plan) could direct other activities/investments of a municipalities/city in terms of the development of this product as well as contribute to better harmonization of activities between partner municipalities/cities and specify responsibility of entities for particular activities leading to the creation of the cross-border tourism product.

A significant role in the process of creating the cross-border tourism product is played by local tourism organizations which should cooperate with their counterparts on the other side of the border in order to complete local cross-border initiatives. Effectiveness of activities undertaken in the process of creating the cross-border tourism product at a local level also depends on the scope of cooperation between particular entities (points and head offices) of tourism information in a region and beyond it. Such cooperation concerns mainly the exchange of information on tourism values or cultural events typical of a given municipality/district/city.

It is also essential that tourism enterprises take part in this process since they provide the majority of elements of this product. They include typical tourism enterprises providing accommodation, catering, transport and guide services, equipment rentals for tourists, etc., as well as enterprises providing services for residents of a region and tourists (e.g. retail outlets, galleries, cinemas, theatres, health service, banks, etc.). From the perspective of sales of the cross-border tourism product, a significant role is played by travel agencies which are entities specialized in organizing and brokering in tourism. They include travel agencies and travel brokers who sell offers from providers of tourism services to tourists, as well as entities, which apart from brokering, organize tourism events and provide their own tourism services (tour operators).

In the process of creating the cross-border tourism product, it is essential that primarily entities of regional and local tourism policy cooperate in terms of common tourism infrastructure (e.g. tourist trails and their development), agreements on common forms of promotion of a crossborder tourism product as well as financial support for cross-border tourism initiatives. Tourism enterprises influence the structure of a product. 


\section{Entities influencing the form of the cross-border tourism product in the West Pomerania Province and Mecklenbury-Vorpommern}

The West Pomerania Province is located in the north-east of Poland. To the west, it directly borders with the German Land of Mecklenburg-Vorpommern. These regions share many similar characteristics. Apart from the comparable area (23 thousand $\mathrm{km}^{2}$ ) and population $(1.7 \mathrm{~m})$, they have much the same conditions for tourism. This mainly results from being located by the Baltic Sea, rich and diverse network of waterways, topography and existence of numerous tourism values, i.e. rivers, lakes, lakelands, forms of nature conservation and historical monuments. Furthermore, these regions are characterized by a well-developed accommodation base, high number of tourists using lodging in collective tourist accommodations as well as good transport accessibility. In the light of the above conditions, the West Pomerania Province and Mecklenburg-Vorpommern are predisposed to developing common tourism products.

Many entities participate in the development of the cross-border tourism product of the regions. One of them is Euroregion Pomerania which represents the cross-border interests of Poland, Germany and Sweden. ${ }^{8}$ The German side in Euroregion is represented by Kommunalgemeinschaft Pomerania e.V. (the Association of Local Authorities Europaregion Pomerania) with the head office in Löcknitz that consociates two districts of the Federal State of Brandenburg (Barnim, Uckermark) and three districts of the Federal State of Mecklenburg-Vorpommern (VorpommernGreifswald, Vorpommern-Rügen and Mecklenburgische Seenplatte). ${ }^{9}$ The Polish side is represented by the Association of Polish Local Authorities of the Euroregion Pomerania (SGPEP in Polish Stowarzyszenie Gmin Polskich Euroregionu Pomerania) that consociates almost all municipalities of the West Pomerania Province including the City of Szczecin.

The contribution of the Association of Polish Local Authorities of the Euroregion Pomerania in developing the cross-border tourism product involves, among other aspects, the use of EU financial instruments. Euroregion Pomerania is a representative of the Polish members of SGPEP in the EU Initiative Interreg IVA Monitoring Committee of the West Pomerania Province/MecklenburgVorpommern/Brandenburg ${ }^{10}$ deciding on which proposals are retained for possible funding, including the proposals related to developing common tourism products. Moreover, the Euregion's employees work in the Common Technical Office in Löcknitz which collects and prepares proposals on common infrastructure initiatives (including tourism-related ones). A network of the Service and Advisory Centres of Euroregion Pomerania has also been created within the framework of the Interreg IVA programme. In Poland, these centres are located in Koszalin,

\footnotetext{
${ }^{8}$ The tourism potential of the Skåne region is not being considered in terms of the development of a cross-border tourism product due to having no land connection with that region. Moreover, the involvement of the Skåne Assosciation of Local Authorities in the Euroregional cooperation is less intense than of their Polish and German counterparts.

${ }^{9}$ The number of member municipalities was reduced as a result of administration reforms in Mecklenburg of 4 September 2011. In accordance with the Act of Landtag of Mecklenburg-Vorpommern of 12 July 2010 (Gesetz- und Verordnungsblatt für Mecklenburg-Vorpommern 2010, No. 13, p.366) the number of districts was reduced from 12 to 6 and, out of 6 self-administrating cities, 2 were left.

${ }^{10}$ It will be known as Interreg VA Programme in the financial perspective of 2014-2020.
} 
Karlin, Szczecin, Myślibórz and Dębno, whereas in Germany they are located in the cities of Greifswald, Neubrandenburg and Schwedt/Oder. In this respect, the contribution of Euroregion Pomerania in the process of developing a cross-border tourism product mainly involves matching potential tourism partners that may combine their offer in the cross-border tourism product or develop a cross-border product on the basis of particular elements of the region's tourism potential.

A place for sharing experiences and finding German partners are conferences and tourism seminars organized by the Service and Advisory Centres. One can list the following organized tourism meetings: the Polish-Germany Forum for Tourism Industry Entrepreneurs, a tourism industry seminars "Prolonging the Tourism Season on the Baltic Sea Seaside" and "Tourism Product of Euroregion Pomerania", the Polish-Germany conference "Tourism Navigation Markers for Water Sports in the Euroregion Pomerania".

Together with their German partner Kommunalgemeinschaft Pomerania e.V, the Association of Polish Local Authorities of the Euroregion Pomerania has been implementing the Small Project Fund of Interreg IVA. These are funds for the implementation of the so-called micro-projects, which aim is to intensify cooperation between communities on both sides of the border and to overcome existing barriers in terms of mutual contacts. Projects eligible for funding are initiatives that improve cooperation in different areas of social life. There were 131 projects funded in 2012 (144 projects in 2010, 123 projects in 2011). ${ }^{11}$ The aim of cross-border initiatives is to develop a partner dialogue and their main activities concern organizing workshops, concerts, integration meetings, film festivals, sport events, competitions etc. Among these projects, there are also such tourism initiatives as:

- Polish-German adventure hiking runs in the nature park "Valley of Love",

- International Cycling Races in the Parsęta River Basin, Polish-German Tourism Meetings,

- Cross-border Conference "Our Border - Vision and Reality",

- Tourist and Cultural Cedynia,

- Polish-German Days of the Szczecin Lagoon "Trzebieskie Netpunalia”.

The listed projects are soft projects ${ }^{12}$ and they do not focus on the direct development of the cross-border tourism product, but indirectly influence its structure by launching mutual tourism initiatives. Previous experience shows how significant role small projects play in creating crossborder relations and connections between people. They strengthen the Polish-German cooperation and are an excellent base for next common partner initiatives of residents which in turn lead to a common offer of the cross-border region.

At a regional level, regional authorities and regional tourism organizations are entities that influence the development of cross-border tourism product. Due to the different political systems of Poland and Germany, the structure of regional entities of the researched region is not identical. The German federal system determines a more complex structure of public administration organization than that of a unitary state such as Poland. The regional authorities of the West

\footnotetext{
11 www.pomerania.org.pl (29 May 2015).

12 Soft projects mean non-investment projects, usually of a small scope including such activities as training, scholarships, partnerships, cultural and educational events, etc.
} 
Pomerania Province are represented by the Marshal of the Province, while this function is held by the Prime Minister and the Parliament (Landtag) in the Federal State of MecklenburgVorpommern. ${ }^{13}$ The Department of International Cooperation in the Marshal's Office of the West Pomerania Province collaborates with the Landtag of Mecklenburg-Vorpommern mainly at social, cultural, economic, local government and political levels. In terms of tourism, the Department of Tourism, Economy and Promotion in the Marshal's Office of the West Pomerania Province and the Ministry of Economic Affairs, Construction and Tourism (Ministerium für Wirtschaft, Bau und Tourismus Mecklenburg-Vorpommern) are responsible for cross-border cooperation. ${ }^{14}$ The contribution of the Department and the Ministry into the development of the cross-border tourism product mainly involves institutional support of common project initiatives launched by regional and local tourism organizations as well as partner towns and municipalities. However, reciprocal cooperation is impeded due to incompatible administrative systems.

A similar situation can be observed in the case of regional tourism organizations, which have a direct influence on the structure of the cross-border tourism product. There is one regional tourism organization in the West Pomerania Province, namely the Regional Tourism Organization of the West Pomerania Province (ZROT, in Polish Zachodniopomorska Regionalna Organizacja Turystyczna). This entity was founded in 2000 under a resolution of the Local Government Assembly of the West Pomeranian Province. The Articles of ZROT adopted on the founding meeting on 15 February 2001 state that the goal and task of the organization is to create an image of the Province as a region attractive to tourists. ${ }^{15}$ Furthermore, ZROT is a forum for cooperation between local governments, professional industry organizations and tourism business entities from the West Pomeranian Province. There are 100 entities associated in the organization ${ }^{16}$ (32 enterprises, 30 local government bodies, 19 tourism associations and chambers, 15 local tourism organizations and 3 tourism-related entities).

Whereas in Mecklenburg, there are 9 regional tourism organizations in the form of tourism associations which scope of activities includes areas of particular tourism regions of Mecklenburg. Tourismusverband Mecklenburg-Vorpommern e.V (TMV) takes the role of a parent (so-called umbrella) organization, where all other tourism associations and entities directly or indirectly connected with tourism are members. TMV is responsible for all promotional activities, mainly for creating a brand and implementing common tourism marketing for the region. The goal of the organization is also to take actions that would encourage tourists to visit Mecklenburg and to raise

${ }^{13}$ The Cabinet of the Federal State of Mecklenburg-Vorpommern discusses questions of political principle and decides on bills which it then proposes in the State Parliament. The members of the Cabinet of the Federal State of Mecklenburg-Vorpommern include the Minister-President as well as the Ministers of eight functional Ministries: Minister of the Internal Affairs and Sport, Minister of Justice, Minister of Finance, Minister of Economic Affairs, Construction and Tourism, Minister of Agriculture, Environment and Consumer Protection, Minister of Education, Science and Culture, Minister of Energy, Infrastructure and State Development, and Minister of Employment, Gender Equality and Social Affairs.

14 Section 240 is responsible for tourism in the Ministry for Economic Affairs, Construction and Tourism.

15 The Articles of Organization of the Regional Tourism Organization of the West Pomeranian Province passed on 15 February 2001, as amended.

16 www.zrot.pl (20 June 2015). 
the quality of the tourism offer. To encourage fulfilment of these tasks, quality seals, issued based on objective criteria, are awarded in such areas as: travel for young people, water tourism or the wellness sector.

At a regional level, we should also mention the "Berlin-Szczecin-Baltic Waterway" Cross-border Cluster which goal is to promote water and land tourism along the waterway as a leading tourism offer of the West Pomeranian Province. The cluster focuses on the cooperation of various entities operating in the border area to correlate individual activities of municipalities, dates of cultural as well as recreational and sport events in order to develop a common tourism product with the same brand. Tourists can enjoy 25 Polish and 80 German marinas across the region covered by the partner group around the Szczecin and Kamien Lagoons, the Wolin, Usedom and Rugia islands, the Lake Dąbie and Międzyodrze (the Eastern Odra and the Western Odra rivers).

Thus, the impact of the cluster on the development of the cross-border tourism product is connected with creating an international waterway. However, the cluster should strive to expand its activity by including other forms of tourism, then, other entities connected with the development of tourism in the analysed area would enter its structure. The tourism cluster approach is a desired solution for the development of the cross-border tourism product. The value chain created in this process, by individual providers of tourist services, suggests cooperation and synergy resulting from it.

At a local level, local government bodies and local tourism organizations are entities that develop the cross-border tourism product. Municipalities and towns cooperate with their counterparts on the other side of the border. This cooperation is conducted based on partnership between municipalities, towns and districts. One of the focuses of partnership cooperation are tourism initiatives which goal is to combine particular elements of a tourism product into one coherent product. It is difficult to precisely determine the number of local tourism organizations in the West Pomeranian Province. ${ }^{17}$ According to the data available at the website of the Forum for Local Tourism Organizations and the data of the Regional Tourism Organization of the West Pomeranian Province, it has been established that there are, in total, 22 local tourism organizations operating in the West Pomeranian Province. Moreover, regulations of the Polish law ${ }^{18}$ on the form of activities of the Local Tourism Organizations in Poland significantly limit the possibilities of

${ }^{17}$ It is due to the fact that there is no uniform database that would include information on all tourism organizations operating in the region. In order to analyse local tourism organizations, one can use the electronic list of the National Court Register, however, data retrieved in this way may be imprecise. Some local tourism organizations may be registered there but do not operate anymore, while other may not have been registered in the National Court Register yet as they are in the process of registering or preparing for this procedure but already operating. Another source of information on local tourism organizations in the region may be the Regional Tourism Organization of the West Pomeranian Province. However, it only keeps record of local tourism organizations that are members of ZROT. Such data is also available on the list of local tourism organizations published on the website of the Polish Tourism Organization. Some local tourism organizations are entities created for the purpose of local partner groups set up as part of projects implemented by the Regional Tourism Forum.

${ }^{18}$ In accordance with the provisions of the Act on Polish Travel Organization, local tourism organizations must be associations. 
functioning of and developing such types of entities. As a consequence, these organizations have few possibilities of implementing large, complex, international or cross-border projects.

Local tourism organizations exist in a different form in Mecklenburg-Vorpommern than in the West Pomeranian Province. Entities that deal with local marketing or provide tourist information services may be called local tourism organizations. The structure of these entities includes the following elements:

1. Tourism centres (Tourismuszentrale) - serving as tourist information points and a booking system for tourist services. They are financed by town or municipality offices. Examples of such entities include: Tourismuszentrale Hansestadt Rostock und Warnemünde, Tourismuszentrale Hansestadt Stralsund, Tourist - Information Hansestadt Wismar.

2. Urban marketing bodies (Stadtmarketing) - dealing with tourism marketing of a particular town. In Mecklenburg-Vorpommern, these bodies function as tourism associations (Fremdenverkehrsverein der Hansestadt Greifswald und Land e.V.) or an independent department of a town office (Stadt Neubrandenburg, Fachbereich Kultur, Stadtmarketing, Schule und Sport).

3. Commercial companies - dealing with tourism marketing, sales of tourist services, but also functioning as tourist information points in a given area (e.g. Tourismuszentrale Rügen GmbH, ${ }^{19}$ Usedom Tourismus GmbH, ${ }^{20}$ Stadtmarketing Gesellschaft Schwerin GmbH).

There are discernible differences between the functioning and responsibilities of tourism entities in the West Pomeranian Province and Mecklenburg-Vorpommern. The division of responsibilities between various entities seems to be more transparent in Mecklenburg than in the West Pomeranian Province. Ministerium für Wirtschaft, Bau und Tourismus carries out the management function, sets out the framework for the development of tourism in the Mecklenburg region and introduces infrastructure solutions enabling further development of tourism in the region. While Tourismusverband Mecklenburg-Vorpommern receives funding from the Ministry for its activities and functions as a marketing agency. It is responsible for implementation of any promotional activities on the internal and external markets (incl. tourism trade fairs, publishing houses, television spots, press advertisement). Such a division of responsibilities between the local administration and the tourism organization is very beneficial. Responsibilities are not doubled which is often the case with Department of Tourism, Economy and Promotion in the Marshal's Office of the West Pomeranian Province and the Regional Tourism Organization of the West Pomeranian Province. Furthermore, TMV promotes Mecklenburg as a one, coherent tourism region and additionally the other eight tourism associations conduct intensified activities in the

${ }^{19}$ Gesellschaft mit beschränkter Haftung $(\mathrm{GmbH})$ is the most common form of a capital company in Germany. In some aspects German GmbH is similar to the Polish spótka z ograniczona odpowiedzialnościa or the English limited liability company.

${ }^{20}$ Usedom Tourismus GmbH was founded in 2001 by a regional tourism organization Tourismusverband Insel Usedom e.V. All marketing and promotional activities for the German part of the Usedom island were handed over to that company. Shareholders of this company include an association of imperial resorts (KaiserbäderTourismusService GmbH), the coastal railway of Usedom (Usedomer Bäderbahn $\mathrm{GmbH}$ ) and a regional tourism organization (Tourismusverband Insel Usedom e.V.). 
scope of tourism development and promotion of a tourism offer. They are focused on particular tourism areas of Mecklenburg, i.e. Rugia, Usedom, the Mecklenburg Lake District, Vorpommern, the Fischland - Darß - Zingst Peninsula and Mecklenburg's Switzerland.

The Regional Tourism Organization of West Pomeranian Province is the only tourism organization operating at a regional level West Pomeranian Province. Even though it cooperates with local tourism organizations as part of membership in the organization structure, this cooperation is insufficient. Most of the local tourism organizations are not able to cope with financial problems. There are not enough funds in the budget of the organizations to conduct professional promotional activities of a tourism offer of a particular area (municipality, district, group of municipalities and districts). Moreover, there are only 22 local tourism organizations functioning in the voivodeship. This amount is far from satisfactory, taking account of the fact that West Pomeranian Province comprises 114 municipalities and 18 districts $^{21}$.

It is visible that the cooperation with the tourism industry is insufficient in terms of tourism activities conducted together. No precise division of responsibilities is defined what results in a situation where some activities are duplicated and conducted separately by few entities rather than in cooperation. One may also observe that there is competition between different organizations (e.g. over the access to funds for a particular project) which theoretically should cooperate with each other.

\section{Conclusions}

Entities which exist at macro-regional, regional and local levels take part in the process of developing the cross-border tourism product of the West Pomeranian Province and Mecklenburg-Vorpommern. The degree of involvement of each entity depends on the level at which they operate. However, due to the dissimilarity of the Polish and German government systems, there are discrepancies in terms of responsibilities of the entities creating some obstacles for developing common products. It is most visible at regional and local levels.

In order to combine particular elements of the tourism potential of the West Pomeranian Province and Mecklenburg-Vorpommern, it is recommended for municipalities and districts to cooperate through local tourism organizations as they are one of the entities that participate in the development of a cross-border tourism product. It is also desirable that a local tourism organization becomes a partner for the Regional Tourism Organization of the West Pomeranian Province. As a result, a local tourism organization could propose those elements of a tourism product that the regional tourism organization joins together and undertakes to promote it the country and abroad. While the cross-border cooperation between local tourism organizations and their partners from Mecklenburg-Vorpommern should be based on small initiatives and common cultural events that would support the development of neighbourhood relations.

${ }^{21}$ www.stat.gov.pl (2.07.2015). 
At a regional level, it is recommended that responsibilities in terms of the development and promotion of cross-border tourism products are put in order and tasks between the two largest regional bodies in the West Pomeranian Province are divided so that the leading role of ZROT in the process of developing a cross-border tourism product is indicated in its articles of organization. Furthermore, the Regional Tourism Organization of the West Pomeranian Province should take actions in order to commercialize the cross-border tourism product. To achieve that, it is vital to work with travel agencies by providing them with information about the cross-border tourism product that they could add to their offer.

Developing a cross-border tourism product of the West Pomeranian Province and MecklenburgVorpommern will contribute to achieving a synergy effect. Focusing activities of entities from the West Pomeranian Province and Mecklenburg-Vorpommern on developing a common product will lead to better results than activities conducted by each entity on its own. Joining forces and resources will enable to use the tourism potential better through rational management and may generate added value in a form of cutting costs, e.g. of promotional activities.

\section{Referenences}

Dziedzic E. Obszar recepcji turystycznej jako przedmiot zarządzania strategicznego, „Monografie i Opracowania” nr 442, SGH, Warszawa 1998.

Greta M., Euroregiony a integracja europejska. Wnioski dla Polski, Wydawnictwo Uniwersytetu Łódzkiego, Łódź 2003. Holloway J.Ch., Ch. Robinson, Marketing for Tourism, PWE, Warszawa 1997.

Kaczmarek J., Stasiak A., Włodarczyk B., Produkt turystyczny, pomyst, organizacja, zarzadzanie, Polskie Wydawnictwo Ekonomiczne, Warszawa 2005.

Middleton V.T.C., Marketing w turystyce, Polska Agencja Promocji Turystyki, Warszawa 1996.

Kurek W. (ed.)., Turystyka, Wydawnictwo Naukowe PWN, Warszawa 2007.

Wodejko S., Ekonomiczne zagadnienia turystyki, Wyższa Szkoła Handlu i Prawa w Warszawie, Warszawa 1998.

www.pomerania.org.pl.

www.zrot.pl.

www.stat.gov.pl. 


\section{STRUKTURA PODMIOTOWA TRANSGRANICZNEGO PRODUKTU TURYSTYCZNEGO}

SŁOWA KLUCZOWE

STRESZCZENIE transgraniczny produkt turystyczny, podmioty kreujące transgraniczny produkt turystyczny, województwo zachodniopomorskie i Meklemburgia-Pomorze Przednie

Transgraniczny produkt turystyczny stanowi kompilację elementów potencjału turystycznego obszaru transgranicznego, które zaspokajają różnorodne potrzeby turystów. Funkcjonowanie transgranicznego produktu turystycznego jest determinowane przez wiele zróżnicowanych czynników, takich jak np. walory przyrodnicze i antropogeniczne, dostępność komunikacyjna, rodzaj i jakość infrastruktury turystycznej oraz paraturystycznej, czy jakość środowiska przyrodniczego. W proces kreowania wspólnego produktu zaangażowanych jest wiele podmiotów występujących po obu stronach granicy, m.in. regionalne i lokalne organizacje turystyczne, jednostki samorządu terytorialnego oraz inne podmioty zainteresowane rozwojem turystyki. Obszarami, które mogą kształtować wspólny produkt turystyczny jest województwo zachodniopomorskie oraz graniczący od zachodu kraj związkowy Republiki Federalnej Niemiec, Meklemburgia-Pomorze Przednie. W procesie kształtowania wspólnego produktu kluczową rolę odgrywają podmioty występujące na szczeblu regionalnym. Jednakże ze względu na odmienność systemu państwowego Polski i Niemiec, stopień ich zaangażowania w kreację transgranicznego produktu turystycznego jest różny. Celem artykułu jest wskazanie podmiotów biorących udział w procesie kreowania transgranicznego produktu turystycznego oraz określenie ich roli na przykładzie województwa zachodniopomorskiego i Meklemburgii-Pomorze Przednie. 